\title{
Physiological Quality of Common Bean Seeds Subjected to Different Concentrations of Salicylic Acid
}

\author{
Tiéle Stuker Fernandes ${ }^{1}$, Ubirajara Russi Nunes ${ }^{2}$, Rodrigo Roso ${ }^{1}$, Eduardo José Ludwig ${ }^{1}$, Priscila Barbieri Zini ${ }^{1}$, \\ Janine Farias Menegaes ${ }^{1}$, Geovana Facco Barbieri ${ }^{3}$ \& Cassiano Vasconcelos dos Santos ${ }^{3}$ \\ ${ }^{1}$ Postgraduate Program in Agronomy, Federal University of Santa Maria, Santa Maria, Brazil \\ ${ }^{2}$ Department of Crop Science, Federal University of Santa Maria, Santa Maria, Brazil \\ ${ }^{3}$ Graduation in Agronomy Federal University of Santa Maria, Santa Maria, Brazil \\ Correspondence: Tiéle Stuker Fernandes, Postgraduate Program in Agronomy, Federal University of Santa Maria, \\ Avenida Roraima, ${ }^{\circ}$ 1000, Bairro Camobi, CEP: 97105-900, Santa Maria, RS, Brazil. Tel: (55)-99-724-0414. \\ E-mail: tielefernandes@hotmail.com
}

Received: September 8, 2018

Accepted: October 20, 2018

Online Published: December 15, 2018

doi:10.5539/jas.v11n1p448

URL: https://doi.org/10.5539/jas.v11n1p448

The research is financed by CAPES.

\begin{abstract}
Salicylic acid acts on several plant physiological processes. Therefore, the aim of this study was to determine if salicylic acid interferes on the physiological quality of common bean seeds soaked with different concentrations by testing two seed imbibition methodologies. Common bean seeds of the cultivars Fepagro 26 and Predileto were utilized. The seeds were soaked in solutions of salicylic acid with concentrations of zero, 250, 500, 750, $1,000,3,000$ and $5,000 \mu \mathrm{M}$. Seed imbibition occurred in two ways: (1) germination paper moistened with salicylic acid solutions, and (2) seed imbibition in salicylic acid solutions in plastic boxes for 24 hours and subsequent sowing on germination paper moistened with distilled water. The experiment was maintained in a germination incubator under $25{ }^{\circ} \mathrm{C}$ temperature and with constant light. The number of normal seedlings (first count), length, fresh and dry matter of seedlings were determined on the fifth day after sowing. Germination percentage was assessed nine days after sowing. The study was performed in a completely randomized design with four replicates and 50 seeds were used for each treatment. Regression analysis was performed for salicylic acid concentrations, with no comparison of cultivars and seed imbibition methods. Salicylic acid in concentrations up to $1,000 \mu \mathrm{M}$ does not negatively affect the common bean seed germination of the cultivars Fepagro 26 and Predileto, using seed soaking for 24 hours and imbibition in the germination paper. Concentrations of salicylic acid up to $1,000 \mu \mathrm{M}$ and seed imbibition for 24 hours do not affect the vigor (first count) of the two common bean cultivars.
\end{abstract}

Keywords: imbibition, germination, Phaseolus vulgaris L., vigor

\section{Introduction}

Salicylic acid (SA) is a plant hormone widely distributed among plants, which in low concentrations acts on several plant physiological and biochemical processes (Khan et al., 2015). The processes regulated by SA include stomatal closure, nutrient uptake, chlorophyll and protein synthesis, fruit development, foliar abscission, inhibition of ethylene synthesis, seed germination and plant growth (Ashraf et al., 2010; Kadiaglu et al., 2011; Kabiri, Farahdakhsh, \& Nasibi, 2012; Sharafizad et al., 2013).

In addition, $\mathrm{SA}$ is also involved in obtaining specific responses of plants under biotic (Vlot, Desempsey, \& Klessing, 2009) and abiotic stress (Antonic et al., 2016; Moravcová et al., 2018; Mutlu et al., 2016). According to Hayat et al. (2010) and Kang et al. (2014), SA acts as a stress-signaling molecule mediating physiological, biochemical and molecular processes in plants under unfavorable environmental conditions. The SA is responsible for the activation of antioxidant enzymes, such as superoxide dismutase, ascorbate peroxidase, guaiacol peroxidase, catalase, which act on free radicals present in cells, reducing reactive oxygen species (ROS) and lipid peroxidation (Jayakannan et al., 2015). 
Studies have demonstrated that the exogenous application of low concentrations of SA in plants promotes physiological changes, such as increase in plant height, leaf area and stem diameter (Hussein, Balbaa, \& Gaballah, 2007), increased content of photosynthetic pigments (Hayat et al., 2005) and increased germination and seedling growth (Shakirova et al., 2003).

However, the SA effect on seed germination has been controversial, as there are reports suggesting that it may inhibit or increase seed germination potential. These contradictory results may be related to utilized SA concentrations and the application mode on seeds (Horváth et al., 2015; Huang et al., 2016). In Arabidopsis thaliana, Rajjou et al. (2006) found that the exogenous application of 1,000 $\mu \mathrm{M}$ of SA inhibited seed germination for this species. In barley (Hordeum vulgare), concentration of $250 \mu \mathrm{M}$ of SA inhibited seed germination (Xie et al., 2007). Whereas in maize (Zea mays), the germination is completely inhibited when higher concentrations of SA are used, varying from 3,000 to 5,000 $\mu \mathrm{M}$ (Guan \& Scandalios, 1995).

Surveying Vicia faba, Anaya et al. (2018) also observed reduced germination with SA use in concentrations of 250 to $1,000 \mu \mathrm{M}$ in the seed imbibition during eight hours. However, wheat seeds (Triticum aestivum) treated with $50 \mu \mathrm{M}$ of SA expressed greater vigor, obtaining seedlings with higher growth (Shakirova, 2007).

The SA application in the seed imbibition for a certain time, usually hours (Agostini, Machado, Neto, \& Custódio, 2013; Yamamoto et al., 2014) is a common procedure used in scientific researches. In this case, the SA is absorbed along with the water during the beginning of the seed soaking process and then the seeds are submitted to germination in substrates with SA absence. However, in some cases SA is supplied to the seeds continuously throughout germination by wetting the substrate utilized. Thus, the SA stays in contact with the seeds for longer periods, with prominent interference on the germination and vigor (Carvalho et al., 2007).

As verified in the literature, many studies are being conducted with the objective of elucidating the effect of the exogenous SA application on germination and seedling performance parameters of several agricultural species but doubts still exist regarding the concentrations used and the form of seed application. Thus, the aim of this study was to determine if salicylic acid interferes on the physiological quality of common bean seeds soaked with different concentrations by testing two seed imbibition methodologies.

\section{Material and Methods}

The study was performed at the Seed Research and Teaching Laboratory (LDPS) of the Department of Plant Science in the Federal University of Santa Maria during the months of January and February 2017. Common bean (Phaseolus vulgaris L.) seeds of the cultivars Fepagro 26 and Predileto were used. The seeds used in this study were produced in the experimental area of the Department of Plant Science from September to December 2016. Moreover, the cultural treatments were carried out according to the technical agronomical indications for the crop. After manual harvesting, the seeds were separated by size in order to standardize the material used in the study.

Initially the seeds were assessed for physical and physiological traits by the following tests:

Thousand Seed Weight: eight replicates of 100 seeds were weighed, determining the weight of 1000 seeds according to the Rules for Seed Analysis (RAS) (Brazil, 2009).

Moisture Degree: determined by the oven method at $105^{\circ} \mathrm{C}$ for 24 hours, using two $5 \mathrm{~g}$ subsamples, according to Brazil (2009).

Germination Test: four replicates of 50 seeds were seeded on a roll of germination paper moistened with distilled water in the ratio of 2.5 times the dry paper weight. The rolls were kept in a germination incubator (BOD) under constant light and temperature of $25^{\circ} \mathrm{C}$. The germination evaluation was performed on the ninth day after sowing and the results were expressed as percentage of normal seedlings (Brazil, 2009).

First Germination Count: performed along with the germination test and the percentage of normal seedlings was determined on the fifth day after the test installation (Brazil, 2009).

Seedling Length: carried out with four replicates of 20 seeds, sown in two rows mismatched in the upper third of the germination paper and kept in the same condition as the germination test. On the fifth day after sowing ten normal seedlings of each replicate were measured with graduated water, according to Nakagawa (1999). It was determined: length of shoot, comprising between the root and the insertion of cotyledons; root length; and, total length, being the summation of the root and shoot.

Seedling Dry Matter: ten normal seedlings from the length test were separated in shoot and root and taken to an oven at $65^{\circ} \mathrm{C}$ for 48 hours to determine the seedling dry matter (Nakagawa, 1999). 
Field Emergence: four replicates of 50 seeds were sown in $1 \mathrm{~m}$ rows with spacing of $0.2 \mathrm{~m}$ between each row and in furrows of $0.03 \mathrm{~m}$ depth. The number of seedlings emerged was evaluated daily to determine the mean time of emergence (MTE) as described by Edmond and Drapala (1958). The emergence evaluation was performed on the ninth day after sowing, considering emerged seedlings the ones whose cotyledons no longer touched the soil surface. The result was expressed as an emergence percentage.

After characterization, the seeds were submitted to germination under different concentrations of salicylic acid (SA) (Sigma-Aldrich $\AA$ ): zero, 250, 500, 750, 1,000, 3,000 and 5,000 $\mu \mathrm{M}$. The SA was supplied to the seeds in two ways: (1) in the germinated paper moistened with the SA solutions; (2) seed imbibition in SA solutions in plastic boxes (gerbox) for 24 hours. In the first case, 50 seeds were sown on rolls of germination paper with the SA solutions listed above in the ratio of 2.5 times the dry paper weight. The rolls were packed in plastic bags and kept in a germination incubator (BOD) under constant light and temperature of $25^{\circ} \mathrm{C}$.

In the second case, 50 seeds were placed to be soaked in plastic boxes on three germination paper sheets moistened with $25 \mathrm{~mL}$ of SA solution at the concentrations listed above. The seeds remained soaked for 24 hours in BOD under constant light and temperature of $25^{\circ} \mathrm{C}$. After this imbibition period, the seeds were placed to germinate on germinated paper moistened only with distilled water, in the proportion of 2.5 times the dry paper weight. The rolls were packed in plastic bags and kept in BOD under continuous light and temperature of $25^{\circ} \mathrm{C}$.

For both cases, the percentage of normal seedlings of the first count was evaluated on the fifth day after sowing and the germination percentage was assessed on the ninth day, according to Brazil (2009). Also on the fifth day, 10 normal seedlings taken from the upper line of the germination test of each replicate were measured with the help of a millimeter ruler to obtain the length of the shoot and seedling root. The cotyledons were removed from these seedlings and they were sectioned in shoot and root, for later weighing and fresh matter determination. For dry matter determination, the seedlings were placed in paper bags and taken to the oven at $65{ }^{\circ} \mathrm{C}$, where they remained for 48 hours. Subsequently, they were weighed to obtain the dry matter of shoot and seedling root (Nakagawa, 1999).

The study was carried out in a completely randomized design with four replicates per treatment and each replicate was composed of 50 seeds. Initially, the assumptions of the statistical model were verified by means of the software Assistat ${ }^{\circledR}$ (Silva \& Azevedo, 2016). In case of non-compliance of normality of the errors and homogeneity of the variances, the data transformation using the $\sqrt{\mathrm{x}}$ methodology was executed. The percentage data were transformed by the equation: $\arcsin \sqrt{\% / 100}$.

The SA seed imbibition ways (germination paper and in plastic boxes for 24 hours) and the cultivars were analyzed separately. Data were subjected to analysis of variance by the $F$ test $(p<0.05)$ and regression analysis $(\mathrm{p}<0.05)$ using the Sisvar ${ }^{\circledR}$ software (Ferreira, 2011).

\section{Results and Discussion}

The seeds of both common bean (Phaseolus vulgaris L.) cultivars presented adequate humidity for storage and conduction of other tests, according to Silva et al. (2010), besides presenting high seed vigor and germination (Table 1). The data of the characterization of seed lots were not subjected to statistical analysis, since the objective was to demonstrate the initial physical and physiological quality of the seeds. 
Table 1. Degree of moisture content (U), thousand seed weight (TSW), germination (G), first count (FC), shoot length (SL), root length (RL), total seedling length (TSL), dry matter of shoot (DMS), dry matter of root (DMR), total dry matter of seedlings (TDM), field emergence (FE) and mean time of emergence (MTE) of common bean cultivars (Phaseolus vulgaris L.) Fepagro 26 and Predileto

\begin{tabular}{|c|c|c|}
\hline & Fepagro 26 & Predileto \\
\hline $\mathrm{U}(\%)$ & 10.9 & 10.9 \\
\hline TSW (g) & 206.9 & 232.3 \\
\hline G (\%) & 96 & 97 \\
\hline $\mathrm{FC}(\%)$ & 90 & 91 \\
\hline $\mathrm{SL}(\mathrm{cm})$ & 5.63 & 6.63 \\
\hline $\mathrm{RL}(\mathrm{cm})$ & 14.32 & 13.90 \\
\hline TSL (cm) & 19.95 & 20.54 \\
\hline $\operatorname{DMS}\left(\mathrm{mg} \mathrm{pl}^{-1}\right)$ & 35.62 & 34.57 \\
\hline $\operatorname{DMR}\left(\mathrm{mg} \mathrm{pl}^{-1}\right)$ & 18.20 & 16.95 \\
\hline $\operatorname{TDM}\left(\mathrm{mg} \mathrm{pl}^{-1}\right)$ & 53.82 & 51.52 \\
\hline FE $(\%)$ & 100 & 98 \\
\hline MTE (days) & 2.12 & 1.85 \\
\hline
\end{tabular}

Note. $*$ Data not subjected to statistical analysis.

Using the imbibition method in germination paper, the maximum seed germination and first count (vigor) of the cultivar Fepagro 26 were obtained respectively with the concentrations of 642 and 1,075 $\mu \mathrm{M}$ of SA (Figure 1A). However, we observed that the values obtained for these traits remained stable until concentrations close to $1,000 \mu \mathrm{M}$, demonstrating that the exogenous SA application, when in low concentrations, does not affect seed germination of this species under optimal germination conditions of temperature and humidity. Corroborating this finding, Alonso-Ramírez et al. (2009) affirmed that SA application on seeds only has a positive effect on germination under stress conditions, since this plant hormone is not essential for germination and seedling growth under ideal conditions (Lee, Kim, \& Park, 2010).

Reduction in the normal seedlings percentage in the first count and germination was more pronounced at concentrations of $3,000 \mu \mathrm{M}$ and $5,000 \mu \mathrm{M}$ of SA. The negative SA effect on germination is possibly due to oxidative stress induced by the hormone. According to Poór et al. (2011) and Miura and Tada (2014), there is ROS production when the concentration of SA used is very high, especially hydrogen peroxide $\left(\mathrm{H}_{2} \mathrm{O}_{2}\right)$, leading to intense oxidative stress, degradation of membrane lipids, cell death and culminates in reduced or unfeasible seed germination. In plants of Arabidopsis thaliana treated with 1,000 to 5,000 $\mu \mathrm{M}$ of SA, the $\mathrm{H}_{2} \mathrm{O}_{2}$ levels tripled due to increased superoxide dismutase enzyme activity and inactivation of $\mathrm{H}_{2} \mathrm{O}_{2}$ degradation enzymes, i.e., catalase and ascorbate peroxidase (Rao et al., 1997). 

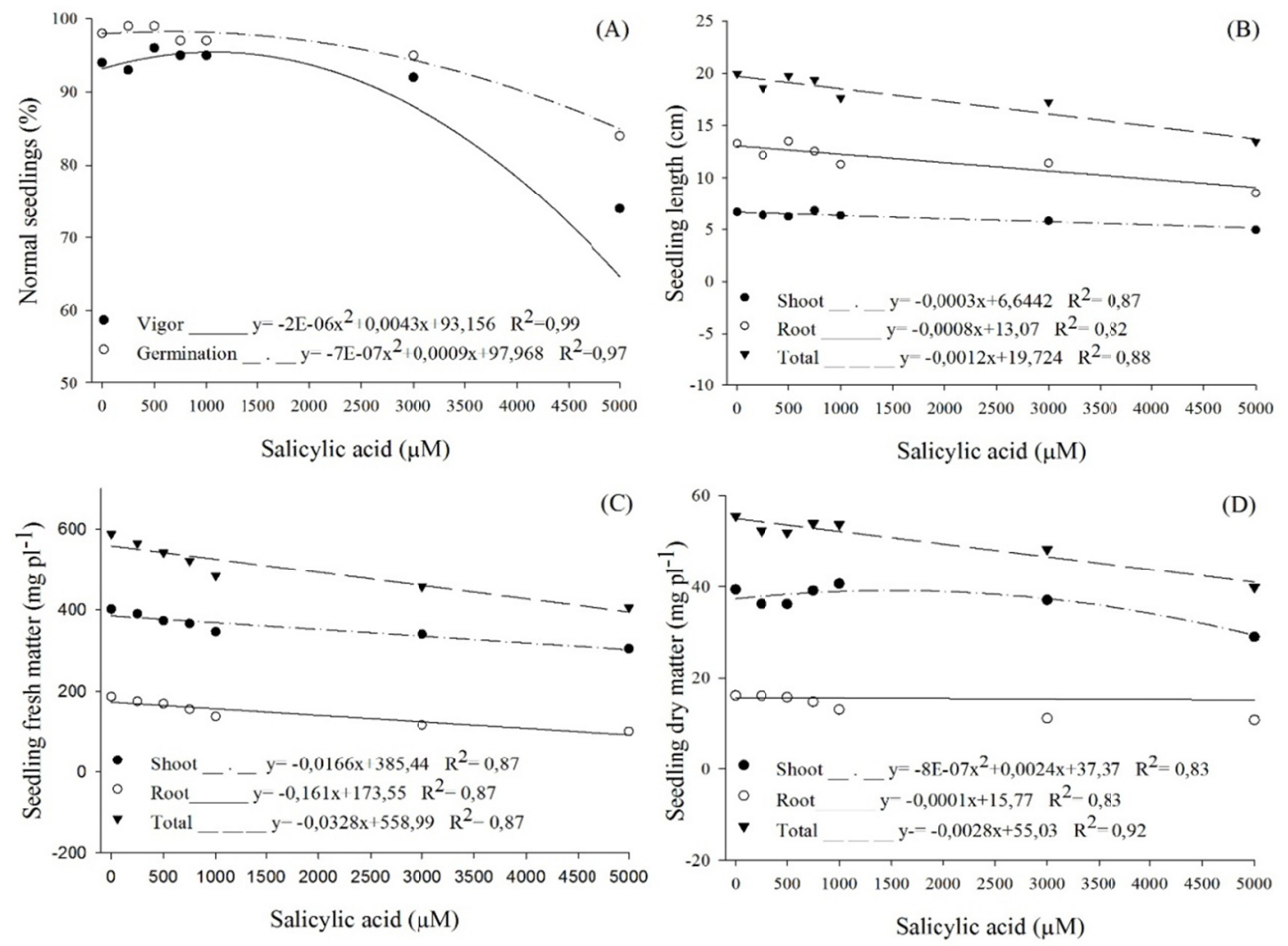

Figure 1. First count (vigor) and germination (A), seedling length (B), seedling fresh matter (C) and seedling dry matter (D) of common bean (Phaseolus vulgaris) of Fepagro 26 cultivar subjected to germination under different concentrations of salicylic acid by the imbibition method with germination paper

The increased SA concentration produces decreasing, adjusting linear equations, for root, shoot and total seedling length (Figure 1B). These results are in agreement with Yamamoto et al. (2014) who observed increase in total length of common bean seedlings soaked in SA for 48 hours.

The results obtained for seedling fresh matter (Figure 1C) correlate with the length, that is, there was a reduction in fresh matter accumulation with SA application. These results were already expected, since the reduction in seedling length (Figure 1B) implies a lower mobilization rate of cotyledon reserves to seedlings, generating seedlings with low fresh matter.

The dry matter of the root and total dry matter of the seedlings were linearly reduced with increased SA concentrations (Figure 1D). However, the dry matter of shoot exhibited quadratic behavior, obtaining a maximum point with $1,500 \mu \mathrm{M}$ SA. In a study conducted with common bean, Agostini, Machado Neto and Custódio (2013) also observed an increase in the dry matter of seedlings with application of SA. However, the authors also verified increased seedling length in their studies, which was not observed in our study.

For the percentage of germination of common bean seeds of the cultivar Predileto submitted to germination with SA application by the imbibition of germination paper (Figure 2A), a quadratic equation was defined with a maximum point in $1,250 \mu \mathrm{M}$ of SA, obtaining 98\% germination. According to Al-Hakimi (2006) and Kabiri, Farahdakhsh and Nasibi (2012), certain concentrations of SA, depending on the species, may promote the activation of antioxidant enzymes, which control ROS during the germination process, reducing lipid peroxidation and stimulating germination. Moreover, Sharafizad et al. (2013) verified that wheat seed imbibition in a solution of $700 \mu \mathrm{M} \mathrm{SA}$ for 24 hours before sowing promoted an increase in seed germination potential while higher concentrations of SA inhibited germination. Likewise, Hajiabbasi, Abbasi and Afshari (2015) verified that AS in concentrations between $100 \mu \mathrm{M}$ and $900 \mu \mathrm{M}$ impaired the germination and vigor of soybean seeds soaked in solution for 6 hours. 

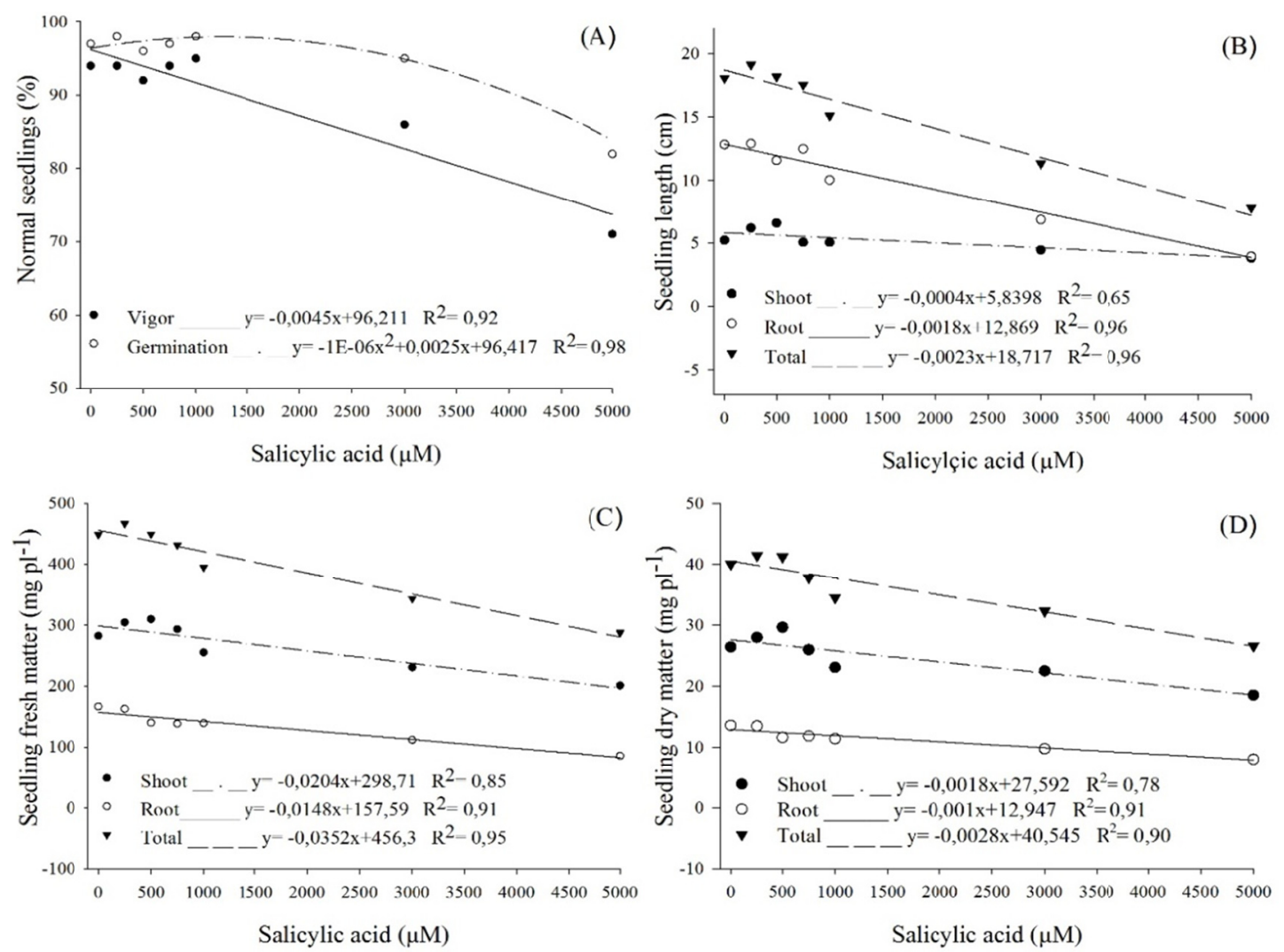

Figure 2. First count (vigor) and germination (A), seedling length (B), seedling fresh matter (C) and seedling dry matter (D) of common bean (Phaseolus vulgaris) of Predileto cultivar subjected to germination under different concentrations of salicylic acid by the imbibition method with germination paper

However, the percentage of normal seedlings (vigor) at the germination test first count was reduced with increasing SA concentration (Figure 2A). The first count is a test of vigor and therefore more sensitive to the treatment of SA when compared to the percentage of germination. Once again, concentrations over 3,000 uM caused an accentuated reduction in germination and vigor, confirming the toxic effect exerted by the product on seed physiological quality.

AS well as in the Fepagro 26 cultivar, the growth of Predileto seedlings submitted to SA was impaired, reducing its length (Figure 2B). In this event, the root length was more affected compared to the shoot length. This result agrees with Tonel et al. (2013), who observed a reduction in the growth of maize seedlings deriving from seeds embedded in 1,000 $\mu \mathrm{M}$ SA for one hour before sowing. Furthermore, this reduction was more pronounced in the root length of the seedlings due to the root remaining in greater contact with the SA.

Reduced accumulation of seedling fresh and dry matter with the use of SA (Figures 2C and 2D) was observed, with adjusted linear equations for all these traits. Thus, according to the results of the length (Figure 2B), fresh mass (Figure 2C) and dry (Figure 2D) of the seedling, the AS reduced the growth and allocation of cotyledon reserves to the seedling. These results corroborate with Ashraf et al. (2010), who demonstrated that SA tends to inhibit plant growth by being antagonistic to auxins, which are responsible for induced plant growth (Gallego-Giraldo et al., 2011; Iglesias, Terrile, \& Casalongué, 2011).

The SA did not affect the germination and percentage of normal seedlings of the first count (vigor) of the Fepagro 26 cultivar when the seeds were soaked in solutions with SA for 24 hours in plastic boxes (Figure 3A). This result can be explained by the fact that the seeds submitted to soaking with SA for only 24 hours probably absorbed less amount of SA, with no changes on seed germination.In this way, the imbibition acted as a seed conditioning, allowing seeds to express their maximum potential. 

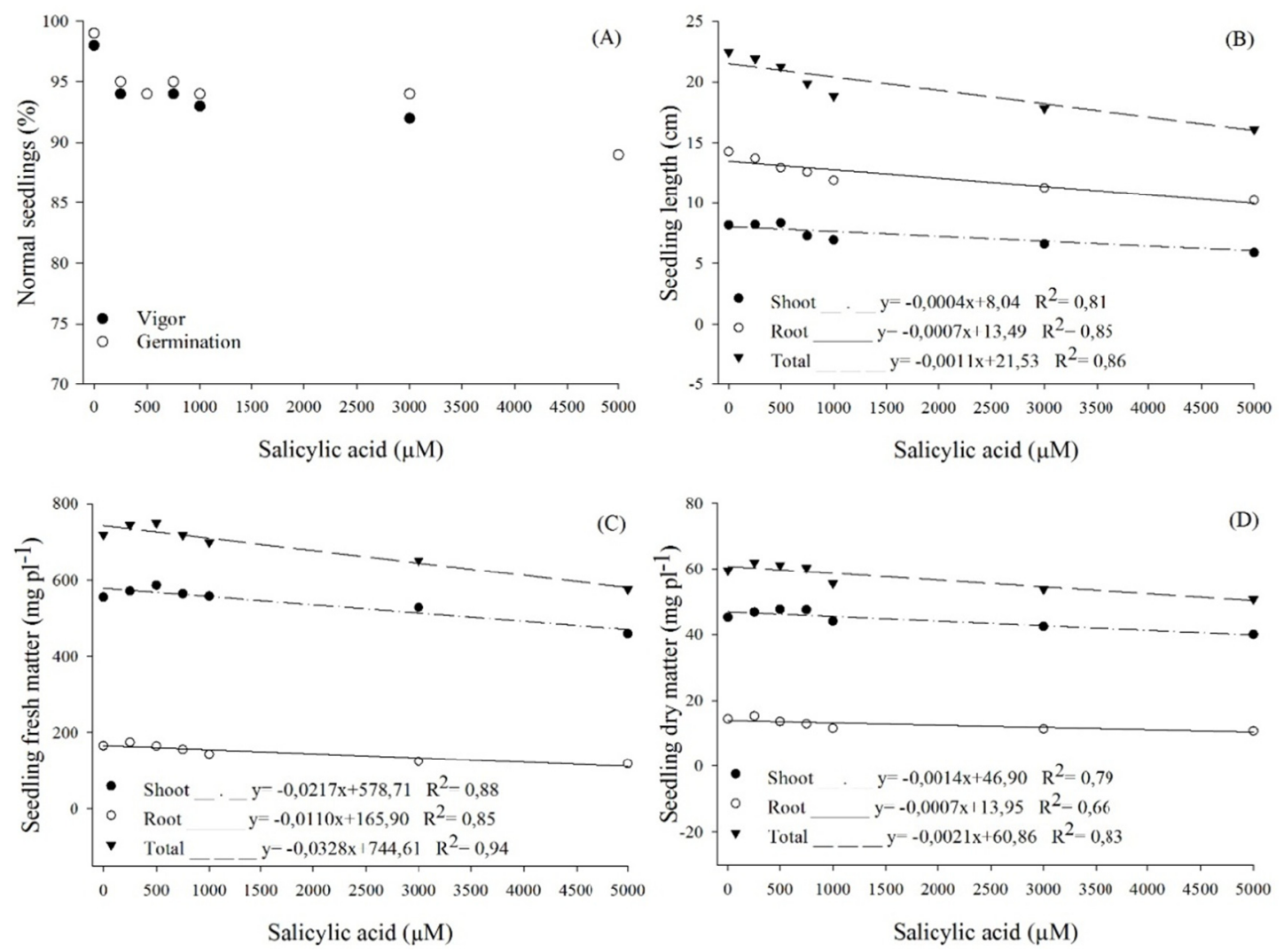

Figure 3. First count (vigor) and germination (A), seedling length (B), seedling fresh matter (C) and seedling dry matter (D) of common bean (Phaseolus vulgaris) of Fepagro 26 cultivar subjected to germination under different concentrations of salicylic acid by the imbibition method in plastic boxes for 24 hours

However, the other traits were affected by the application of SA, as shown in Figure 3. Linear decreasing equations were adjusted for seedling length (Figure 3B), corroborating with the results of fresh (Figure 3C) and dry matter (Figure 3D). This demonstrates that SA hampers the growth and matter accumulation of common bean seedlings.

These results corroborate with those found in saccharine sorghum (Sorghum bicolor) by Lisboa et al. (2017), where SA application reduced the parameters of seedling growth and matter accumulation, including shoot and root length and dry matter of shoot and root.

According to Kerbauy (2008), SA is a plant hormone antagonistic to auxins that are responsible for cell elongation. Therefore, exogenous application of SA, especially at high concentrations, inhibits seedling growth and fresh and dry matter accumulation due to the reduction of endogenous auxin concentrations in the seedlings.

The seed germination and vigor (first count) of Predileto cultivar subjected to SA soaking for 24 hours in plastic boxes were not affected by SA (Figure 4A). In addition, SA did not have a significant effect on shoot length (Figure 4B), fresh matter of shoot (Figure 4C), and dry matter of shoot (Figure 4D) of seedlings.

For the root and total root length (Figure 4B), fresh matter of root and total root (Figure 4C), dry matter of root and total root (Figure 4D), decreasing linear equations were adjusted, since a reduction of these traits with increased SA concentration was observed, confirming the other results verified in this study. 

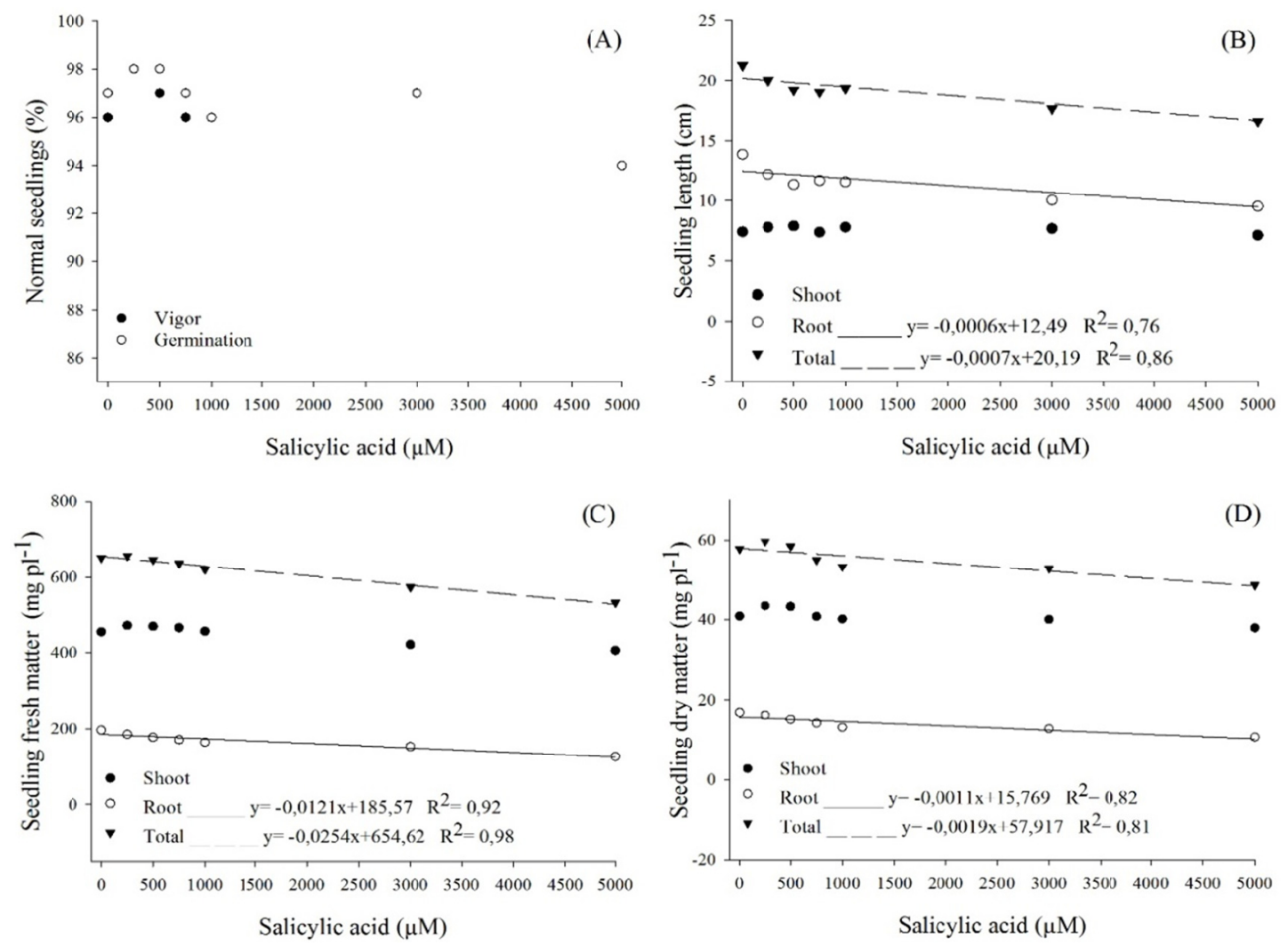

Figure 4. First count (vigor) and germination (A), seedling length (B), seedling fresh matter (C) and seedling dry matter (D) of common bean (Phaseolus vulgaris) of Predileto cultivar subjected to germination under different concentrations of salicylic acid by the imbibition method in plastic boxes for 24 hours

\section{Conclusion}

Salicylic acid in concentrations up to $1,000 \mu \mathrm{M}$ does not negatively affect the common bean seed germination of the cultivars Fepagro 26 and Predileto, using seed soaking for 24 hours and imbibition in the germination paper.

Concentrations of salicylic acid up to $1,000 \mu \mathrm{M}$ and seed imbibition for 24 hours does not affect the vigor (first count) of the two common bean cultivars.

\section{References}

Agostini, E. A. T., Machado Neto, N. B., \& Custódio, C. C. (2013). Induction of water deficit tolerance by cold shock and salicylic acid during germination in the common bean. Acta Scientiarum Agronomy, 35(2), 209-219. https://doi.org/10.4025/actasciagron.v35i2.15967

Al-Hakimi, A. M. A. (2006). Counteraction of drought stress on soybean plants by seed soaking in salicylic acid. International Journal of Botany, 2(4), 421-426. https://doi.org/10.3923/ijb.2006.421.426

Alonso-Ramírez, A., Rodríguez, D., Reyes, D., Jiménez, J. A., Nicolás, G., López-Climent, M., ... Nicolás, C. (2009). Evidence for a role of gibberellins in salicylic acid-modulated early plant responses to abiotic stress in Arabidopsis seeds. Plant Physiology, 150(3), 1335-1344. https://doi.org/10.1104/pp.109.139352

Anaya, F., Fghire, R., Wahbi, S., \& Loutfi, K. (2018). Influence of salicylic acid on seed germination of Vicia faba L. under salt stress. Journal of the Saudi Society of Agricultural Sciences, 17(1), 1-8. https://doi.org/ 10.1016/j.jssas.2015.10.002

Antonic, D., Milosevic, S., Cingel, A., Lojic, M., Trifunovic-Momcilov, M., Petric, M., ... Simonovic, A. (2016). Effects of exogenous salicylic acid on Impatiens walleriana L. grown in vitro under polyethylene glycol-imposed drought. South African Journal of Botany, 105, 226-223. https://doi.org/10.1016/j.sajb. 2016.04.002

Ashraf, M., Akram, N. A., Arteca, R. N., \& Foolad, M. R. (2010). The physiological, biochemical and molecular roles of brassinosteroids and salicylic acid in plant processes and salt tolerance. Critical Reviews in Plant 
Sciences, 29(3), 162-190. https://doi.org/10.1080/07352689.2010.483580

Brasil. (2009). Ministério da Agricultura, Pecuária e Abastecimento. Regras para análise de sementes. Secretaria de Defesa Agropecuária. Brasília: Mapa/ACS.

Carvalho, P. R., Machado Neto, N. B., \& Custódio, C. C. (2007). Ácido salicílico em sementes de calêndula (Calendula officinalis L.) sob diferentes estresses. Revista Brasileira de Sementes, 29(1), 114-124. https://doi.org/10.1590/S0101-31222007000100016

Edmund, J. B., \& Drapala, W. J. (1958). The effects of temperature, sand and soil, and acetone on germination of okra seeds. Proceedings of the American Society for Horticultural Science, 71, 428-434.

Ferreira, D. F. (2011). Sisvar: A computer statistical analysis system. Ciência e Agrotecnologia, 35(6), 1039-1042. https://doi.org/10.1590/S1413-70542011000600001

Gallego-Giraldo, L., Escamilla-Trevino, L., Jackson, L. A., \& Dixon, R. A. (2011). Salicylic acid mediates the reduced growth of lignin down-regulated plants. Proceedings of the National Academy of Science, 108(51), 20814-20819. https://doi.org/10.1073/pnas.1117873108

Guan, L., \& Scandalios, J. G. (1995). Developmentally related responses of maize catalase genesto salicylic acid. Proceedings of National Academy of Science, 92(13), 5930-5934. https://doi.org/10.1073/pnas.92.13.5930

Hayat, Q., Hayat, S., Irfan, M., \& Ahmad, A. (2010). Effect of exogenous salicylic acid under changing environment: A review. Environmental and Experimental Botany, 68(1), 14-25. https://doi.org/10.1016/ j.envexpbot.2009.08.005

Hayat, S., Fariduddin, Q., Ali, B., \& Ahmad, A. (2005). Effect of salicylic acid on growth and enzyme activities of wheat seedlings. Acta Agronomica Hungarica, 53(4), 433-437. https://doi.org/10.1556/AAgr.53.2005.4.9

Hajiabbassi, M., Abbasi, A., \& Afshari, R. T. (2015). Effects of salicylic acid and ethylene on germination improvement of deteriorated seed of Glycine max (L.). Crop Research \& Research Crops, 50(1), 86-94.

Horváth, E., Csiszár, J., Gallé, A., Poór, P., Szepesi, A., \& Tari, I. (2015). Hardening with salicylic acid induces concentration-dependent changes in abscisic acid biosynthesis of tomato under salt stress. Journal of Plant Physiology, 183, 54-63. https://doi.org/10.1016/j.jplph.2015.05.010

Huang, C., Wang, D., Sun, L., \& Wei, L. (2016). Effects of exogenous salicylic acid on the physiological characteristics of Dendobrium officinale under chilling stress. Plant Growth Regulation, 79(2), 199-208. https://doi.org/10.1007/s10725-015-0125-z

Hussein, M. M., Balbaa, L. K., \& Gaballah, M. S. (2007). Salicylic acid and salinity effects on growth of maize plants. Research Journal of Agriculture and Biological Sciences, 3(4), 321-328.

Iglesias, M. J., Terrile, M. C., \& Casalongué, C. A. (2011). Auxin and salicylic acid signalling counteract during the adaptive response to stress. Plant Signalling and Behavior, 6(3), 452-454. https://doi.org/10.4161/ psb.6.3.1467

Jayakannan, M., Bose, J., Babourina, O., Rengel, Z., \& Shabala, S. (2015). Salicylic acid in plant salinity stress signaling and tolerance. Plant Growth Regulation, 76(1), 25-40. https://doi.org/10.1007/s10725-015-0028-z

Kabiri, R., Farahdakssh, H., \& Nasibi, F. (2012). Effect of drought stress and its interaction with salicylic acid on black cumin (Nigella sativa) germination and seedling growth. World Applied Sciences Journal, 18(4), 520-527. https://doi.org/10.5829/idosi.wasj.2012.18.04.878

Kadioglu, A., Saruhan, N., Saglam, A., Terzi, R., \& Acet, T. (2011). Exogenous salicylic acid alleviates effects of long term drought stress and delays leaf rolling by inducing antioxidant system. Plant Growth Regulation, 64(1), 27-37. https://doi.org/10.1007/s10725-010-9532-3

Kang, G., Li, G., \& Guo, T. (2014). Molecular mechanism of salicylic acid-induced abiotic stress tolerance in righer plants. Acta Physiologiae Plantarum, 36(9), 2287-2297. https://doi.org/10.1007/s11738-014-1603-z

Kerbauy, G. B. (2012). Fisiologia Vegetal. Rio de Janeiro: Guanabara Koogan.

Khan, M. I., Fatma, M., Per, T. S., Anjum, N. A., \& Khan, N. A. (2015). Salicylic acid-induced a biotic stress tolerance and underlying mechanism plants. Front Plant Science, 6(462), 1-35. https://doi.org/10.3389/fpls. 2015.00462

Lee, S., Kim, S. G., \& Park, C. M. (2010). Salicylic acid promotes seed germination under high salinity by modulating antioxidant activity in Arabidopsis. New Phytologist, 188(2), 626-637. https://doi.org/10.1111/ j.1469-8137.2010.03378.x 
Lisboa, L. A. M., Lapaz, A. M., Viana, R. S., Leonezi, R. S., \& Figueiredo, P. A. M. (2017) Influência do ácido salicílico no processo germinativo de sementes de cultivares de sorgo sacarino. Acta Iguazu, 6(2), 37-49.

Miura, K., \& Tada, Y. (2014). Regulation of water, salinity, and cold stress responses by salicylic acid. Frontiers Plant Science, 5(4), 1-12. https://doi.org/10.3389/fpls.2014.00004

Moravcová, S., Tuma, J., Ducaiova, Z. K., Waligórski, P., Kula, M., Saja, D., ... Libik-Konieczny, M. (2018). Influence of salicylic acid pretreatment on seeds germination and some defence mechanisms of Zea mays plants under copper stress. Plant Physiology and Biochemistry, 122(1), 19-30. https://doi.org/10.1016/ j.plaphy.2017.11.007

Mutlu, S., Atici, O., Nalbantoglu, B., \& Mete, E. (2016). Exogenous salicylic acid alleviates cold damage by regulating antioxidative system in two barley (Hordeum vulgares L.) cultivars. Frontiers in Life Science, 9(2), 99-109. https://doi.org/10.1080/21553769.2015.1115430

Nakagawa, J. (1999). Testes de vigor baseados na avaliação das plântulas. In F. C. Kryzanowski, R. D. Vieira, \& J. B. França Neto (Eds.), Vigor de sementes: conceitos e testes. Londrina: ABRATES.

Poór, P., Gémes, K., Horváth, F., Szepesi, A., Simon, M. L., \& Tari, I. (2011). Salicylic acid treatment via the rooting medium interferes with stomatal response, $\mathrm{CO}_{2}$ fixation rote and carbohydrate metabolism in tomato, and decrease harmful effects of subsequent salt stress. Plant Biology, 13(1), 105-114. https://doi.org/10.1111/j.1438-8677.2010.00344.x

Rajjou, L., Belghazi, M., Huguet, R., Robin, C., Moreau, A., Job, C., \& Job, D. (2006). Proteomic investigation of the effect of salicylic acid on Arabidopsis seed germination and establishment of early defense mechanisms. Plant Physiology, 141(3), 910-923. https://doi.org/10.1104/pp.106.082057

Rao, M. V., Palivath, G., Ormrod, D. P., Murr, D. P., \& Watkins, C. B. (1997). Influence of salicylic acid on $\mathrm{H}_{2} \mathrm{O}_{2}$ production, oxidative stress, and $\mathrm{H}_{2} \mathrm{O}_{2}$-metabolizing enzymes. Plant Physiology, 115(1), 137-149. https://doi.org/10.1104/pp.115.1.137

Shakirova, F. M., Sakhadutdinova, A. R., Bezrukova, M, V., \& Fatkhutdinova, D. R. (2003). Changes in the hormonal status of wheat seedlings induced by salicylic acid and salinity. Plant Science, 164(3), 317-322. https://doi.org/10.1016/S0168-9452(02)00415-6

Shakirova, F. M. (2007). Role of hormonal system in the manifestation of growth promoting andanti-stress action of salicylic acid. In S. Hayat, \& L. Ahmad (Ed.), A plant hormone. Dordrecht: Springer.

Sharafizad, M., Naderi, A., Atasiadat, S., Sakinejad, T., \& Lak, S. (2013). Effect of salicylic acid pretreatment on germination of wheat under drought stress. Journal of Agricultural Science, 5(3), 179-199. https://doi.org/ 10.5539/jas.v5n3p179

Silva, F. A. S., \& Azevedo, C. A. V. (2016). The Assistat Software Version 7.7 and its use in the analysis of experimental data. African Journal of Agriculture Research, 11(39), 3733-3740. https://doi.org/10.5897/ AJAR2016.11522

Silva, F. S., Porto, A. G., Pascuali, L. C., \& Silva, F. T. C. (2010). Viabilidade do armazenamento de sementes em diferentes embalagens para pequenas propriedades rurais. Revista de Ciências Agro-Ambientais, 8(1), 45-56.

Tonel, F. R., Marini, P., Bandeira, J. M., Moraes, D. M., \& Amarante, L. (2009). Salicylic acid: Physiological and biochemical changes in seeds and seedling subjected to salt stress. Journal of Seed Science, 35(4), 457-465. https://doi.org/10.1590/S2317-15372013000400007

Vlot, A. C., Dempsey, D. A., \& Klessig, D. F. (2009). Salicylic acid, a multifaceted hormone to combat disease. Annual Review of Phytopathology, 47(1), 177-206. https://doi.org/10.1146/annurev.phyto.050908.135202

Xie, Z., Zhang, Z. L., Hanzlik, S., Cook, E., \& Shen, Q. J. (2007). Salicylic acid inhibits gibberellin-induced alpha-amylase expression and seed germination via a pathway involving an abscisic-acid inducible WRKY gene. Plant Molecular Biology, 64(3), 293-303. https://doi.org/10.1007/s11103-007-9152-0

Yamamoto, C. J. T., Leite, R. G. F., Minamiguchi, J. Y., Braga, I., Machado Neto, N. B., \& Custódio, C. C. (2014). Water-deficit tolerance induction during germination of Jalo Precoce bean (Phaseolus vulgaris L.) cultivar. Acta Physiologiae Plantarum, 36(11), 2897-2904. https://doi.org/10.1007/s11738-014-1659-9 


\section{Copyrights}

Copyright for this article is retained by the author(s), with first publication rights granted to the journal.

This is an open-access article distributed under the terms and conditions of the Creative Commons Attribution license (http://creativecommons.org/licenses/by/4.0/). 